University of Nebraska - Lincoln

DigitalCommons@University of Nebraska - Lincoln

1993

\title{
Time-Stratigraphic Reconstruction and Integration of \\ Paleopedologic, Sedimentologic, and Biotic Events (Willwood Formation, Lower Eocene, Northwest Wyoming, U.S.A.)
}

Thomas M. Bown

U.S. Geological Survey

Mary J. Kraus

University of Colorado

Follow this and additional works at: https://digitalcommons.unl.edu/usgsstaffpub

Part of the Earth Sciences Commons

Bown, Thomas M. and Kraus, Mary J., "Time-Stratigraphic Reconstruction and Integration of Paleopedologic, Sedimentologic, and Biotic Events (Willwood Formation, Lower Eocene, Northwest Wyoming, U.S.A.)" (1993). USGS Staff -- Published Research. 206.

https://digitalcommons.unl.edu/usgsstaffpub/206

This Article is brought to you for free and open access by the US Geological Survey at DigitalCommons@University of Nebraska - Lincoln. It has been accepted for inclusion in USGS Staff -- Published Research by an authorized administrator of DigitalCommons@University of Nebraska - Lincoln. 


\title{
Time-Stratigraphic Reconstruction and Integration of Paleopedologic, Sedimentologic, and Biotic Events (Willwood Formation, Lower Eocene, Northwest Wyoming, U.S.A.)
}

\author{
THOMAS M. BOWN \\ U.S. Geological Survey, Denver, CO 80225 \\ MARY J. KRAUS
}

Department of Geological Sciences, University of Colorado, Boulder, CO 80309

PALAIOS, 1993 , V. 8 , p. $68-80$

Relative paleosol maturities are inversely proportional to the accumulation rates of the sediment upon which they formed, and are therefore excellent relative indicators of how much geologic time elapsed between any two horizons. An empirically-based model is advanced using paleosol maturities to estimate the relative geologic time separating any stratigraphic levels within the lower Eocene Willwood Formation. The revised Willwood time stratigraphy from this analysis helps evaluate the nature, tempo, and possible causes of three major episodes of mammalian appearance and disappearance. These faunal events are directly correlated with certain aspects of paleosol evolution in the Willwood Formation. That evolution is tied directly to climatic changes and to varying sediment accumulation rates in response to tectonism.

The first faunal turnover occurs at the base of the Willwood Formation. It coincides with a major increase in pedogenic maturity, reflecting a major decrease in sediment accumulation rate, and accompanying general climatic warming at about the time of the Paleocene-Eocene boundary. Throughout the remainder of Willwood time, there was a gradual, yet continual, decrease in paleosol maturity and degree of hydromorphy, probably related to the progressive structural elevation of the Owl Creek antiform bounding the south and southeast margins of the Bighorn Basin. This gradual decrease was punctuated by two intervals of more significant decline in paleosol maturity and in the incidence of hydromorphic soils. Both intervals are also marked by faunal turnovers. These sed- imentologic and biologic events may reflect tectonic pulses, periods when the rate of basin subsidence increased more rapidly.

\section{INTRODUCTION}

Stratigraphic sequences reflect a complex interplay among sedimentation, erosion, and non-deposition. In alluvial settings, overbank floods are generally of short duration and recur every year or two. During the hiatuses between floods, pedogenesis modifies the alluvium. In fact, the proportion of geologic time represented by soil formation (as opposed to deposition or erosion) in a sequence of alluvial rocks is very large (Kraus and Bown, 1986). Because pedogenic modification was penecontemporaneous with deposition of the parent material, the maturity of alluvial paleosols was partly controlled by the rate at which alluvium accumulated (e.g., Leeder, 1975; Retallack, 1986; Bown and Kraus, 1987). In aggrading alluvial sequences, the faster the rate of sediment accumulation, the less mature are the paleosols.

Both modern (e.g., Bridges, 1973) and ancient studies (e.g., Bown and Kraus, 1987) show that, in aggradational alluvial systems, increasingly mature paleosols occur with increasing distance from a channel belt as a result of slower sediment accumulation rates. Rates decrease because new alluvium from a single flood typically thins away from a channel and areas farther from the channel are flooded less frequently than areas close to the channel (e.g., Bridge and Leeder, 1979). Furthermore, several sequential pro- 


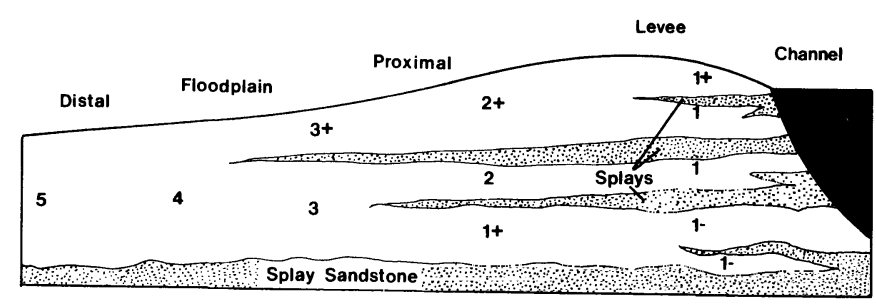

FIGURE 1-Schematic diagram showing pedofacies relations. Numbers refer to paleosol stages. Plus or minus signs indicate a greater or lesser degree of maturity than is typical for a particular stage. A major crevasse-splay sandstone typically forms the base to a pedofacies package. Not to scale.

files may form proximal to the channel during the same time period that a single profile develops in the distal floodplain, where sediment influxes are both thinner and less frequent. Bown and Kraus (1987) used the term pedofacies to describe the lateral changes in paleosol type relative to a channel sandbody. A pedofacies package is a prism of essentially contemporaneous paleosols with vertically stacked and poorly developed paleosols close to a channel sandbody, which grade laterally into coeval floodplain deposits with fewer but more strongly developed paleosols (Fig. 1). Pedofacies are both responsive to and good indicators of: 1) relative short-term net sediment accumulation rates; and 2) the proportionate distribution of geologic time in alluvial rock sequences. To the extent that regional tectonism influences sediment accumulation rates, pedofacies provide a good record of tectonic activity as well (Kraus and Bown, 1986; Kraus, 1987). Formationscale vertical sequences of pedofacies also provide a record of soil paleoenvironments for considerable periods of time.

Pedofacies relationships were first worked out in the lower Eocene Willwood Formation of northwest Wyoming, an alluvial unit about $700 \mathrm{~m}$ thick with numerous stacked pedofacies (Bown and Kraus, 1987; Kraus, 1987). This paper expands upon those earlier studies and examines the relationship of Willwood pedofacies to fluvial sedimentation, geologic time, and paleobiologic events. The first part of the paper focuses on temporally reconstructing the Willwood section based on pedofacies. We then use this temporal framework to document significant episodes of faunal turnover. Lastly, the faunal events are evaluated in light of changes in paleosol maturity and hydromorphy through Willwood time.

\section{TIME STRATIGRAPHIC RECONSTRUCTION}

For many formation-rank units for which some estimate of their approximate duration is known but for which intraformational controls are wholly lacking, a common method for approximating sediment accumulation rates (and paleobiologic tempo) is to divide sediment thickness by estimates of duration in years (e.g., Gingerich, 1983, regarding estimates of Willwood sediment accumulation). Although this approach has some value for large-scale studies, it clearly lacks the resolution and control necessary to place critical geologic (and paleobiologic) events in their proper temporal perspective. Lack of definitive control becomes an especially obdurate problem in cases in which sediment accumulation rates changed considerably through time. In addition, resolution of the temporal contributions of periods of erosion and non-deposition, largely ignored in such studies, has been a formidable obstacle to progress in temporal sequencing within formation-rank alluvial units. When it is recognized that nearly all alluvial units contain paleosols and that the temporal nature of paleosols is, by definition, hiatal, the significance of paleosol studies to elucidating sediment accumulation rates is clearly critical.

In developing the paleosol maturation sequence and pedofacies model for paleosols of the Willwood Formation (Bown, 1985; Kraus and Bown, 1986; Bown and Kraus, 1987; Kraus, 1987), it became clear that pedofacies analyses possess great potential for establishing a technique whereby fluvial suites containing numerous, superposed paleosols, could be temporally sequenced in a relative, yet empirically based manner without recourse to either biostratigraphy or geochronologic determinations. What had been lacking until recently was a determinative basis for assessing the relative proportion of time represented by paleosols of different maturities. A mechanism of proportional temporal sequencing of fluvial rocks has obvious utility for assessing geologic and paleobiologic tempo in event stratigraphy and biostratigraphy, and has unique applications for rocks for which this tempo cannot be assessed by more conventional means. We stress that, given the coarseness of current strategies for determining fluvial tempo, any empirically-based technique for more precisely apportioning geologic and paleobiologic events in time is a substantial improvement.

Wheeler (1958) first introduced the possibility of constructing time-stratigraphic cross-sections, or "chronostratigraphic charts" in sequence stratigraphic parlance (e.g., Vail et al., 1984). Embroidering on concepts developed partly by Blackwelder (1909), Wheeler (1958, p. 1050) conceived of subjective time-stratigraphic units as

“... all three-dimensional entities (material, non-material, or combinations of both) ... which are defined in a framework consisting of two lateral space dimensions and a vertical time dimension." These units “... must delineate all interpreted deposition combination of these may be useful in the interpretation and visualization of geologic history."

Wheeler introduced the "holostrome", which is a timestratigraphic unit representing the temporal record of both preserved strata and strata removed by erosion. The lithostratigraphic unit on which the holostrome is based and which is now the basis for sequence stratigraphic analysis is the "sequence". Basically following Sloss et al. (1949), Wheeler (1958) and later Vail et al. (1984) used sequence to designate genetically related strata separated from overlying and underlying rocks by unconformities. Time-stratigraphic cross-sections or chronostratigraphic charts include not only reconstructed holostromes but also hiatuses. 
These are time intervals represented by no significant deposition.

Although Wheeler advanced these concepts through his studies of transgressive and regressive sequences, as have more recent proponents of sequence stratigraphy, Wheeler clearly recognized their applicability to the correlation and temporal reconstruction of sequences of any origin. His work was the first serious and comprehensive effort to direct geologists toward the possibilities of the relative apportionment of geologic time in actual rock columns (see also Friend et al., 1989).

Several studies have used paleosols to temporally reconstruct non-marine sequences, although with slightly different approaches (e.g., Retallack, 1984; Retallack, 1986; Kraus and Bown, 1986). Temporal restoration of the Willwood Formation follows methods described by Bown and Larriestra (1990). Those authors used different maturities of paleosols and their relationships to erosional unconformities to temporally restore the dominantly pyroclastic eolian lower Miocene Pinturas Formation of Argentina. Pinturas rocks are exposed in widely separated outcrops that cannot be directly correlated and are divisible into three units (sequences) by intraformational unconformities. Such unconformities also bound the Pinturas Formation as its base and top.

Bown and Larriestra (1990) first reconstructed a composite Pinturas rock section by adding rock from sections where it is present to sections where it had been eroded. In addition to the unconformities separating sequences, erosional scours are numerous in the Pinturas Formation and their effect was erased by adding the corresponding rock thickness preserved in sections lateral to the scours. Following the lithostratigraphic reconstruction, a chronostratigraphic cross-section of the Pinturas Formation was developed by temporally weighting the paleosols of different maturities relative to one another (e.g., a Stage 2 paleosol took twice as long to form as a Stage 1 paleosol). Total Pinturas time is represented by the sum of the temporal weights for completely restored vertical sequence of Pinturas paleosols. The portion of total Pinturas time represented by any smaller part of the section can then be determined from the relative time assigned to paleosols in that smaller section.

\section{TIME STRATIGRAPHIC RESTORATION OF THE WILLWOOD FORMATION}

\section{Introduction}

The Willwood Formation of the southern Bighorn Basin (Fig. 2) consists of about $700 \mathrm{~m}$ of alluvial rocks (e.g., Van Houten, 1944; Neasham and Vondra, 1972). Paleosols are developed on nearly all Willwood floodplain deposits and have been intensely studied (e.g., Neasham and Vondra, 1972; Bown, 1979; Bown and Kraus, 1981a, b, 1987; Kraus and Bown, 1986; Kraus, 1987). In addition to the records of deposition and hiatuses preserved in the paleosols, erosional scours are numerous in the Willwood Formation. They are of two types: (1) scours developed at the bases

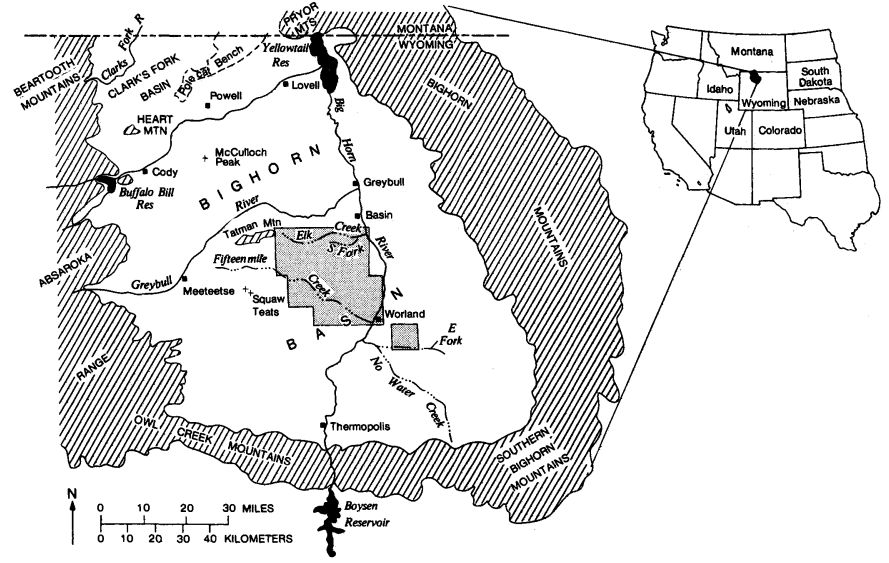

FIGURE 2-Map of Bighorn Basin in northwest Wyoming, U.S.A., showing study area (fine shading).

of sandy channel deposits (sand-floored scours), and (2) scours of greater magnitude and regional extent that record episodes of baselevel lowering and consequent regional erosion (generally mud-floored scours). Both represent missing time due to erosion and non-deposition that must be estimated to reconstruct the Willwood temporal history.

Scouring at the bases of large Willwood channel sandbodies is generally no more than about $4 \mathrm{~m}$ and its temporal consequence can be assessed from sections of paleosol-rich floodplain mudrocks lateral to the channel scours and sandbodies. The temporal import of more regional scours, such as that separating the middle and upper thirds of the Willwood Formation over much of the southern Bighorn Basin (Bown, 1984), was restored in two ways-each acting as a check on the other. First, mudrocks lateral to the regional scour and containing the paleosols that developed coeval with the scour were substituted for the rock record within the scour. Second, the records of deposition and paleosol formation represented by rocks within the regional scour were utilized directly. Both approaches have their drawbacks: the first omits the time represented by the deposition of channel sandbodies, which cannot be directly assessed except by correlation with mudrocks in even more distant sections (and some cannot be evaluated at all, owing to vagaries of outcrop pattern); and the second does not account for time represented by the removed strata. Although sandbody formation and scour development took time that cannot always be restored, on a formation-wide scale the temporal record of depositional and erosional events is relatively insignificant compared with the vast record of hiatal (paleosol) time (e.g., Kraus and Bown, 1986). In addition, many of the channel sandbodies are ribbons deposited by crevasse-splay channels. The time needed to deposit the ribbons or to excavate shallow scours is effectively very small and is therefore accorded a value of zero.

In summary, large channel sandbodies and extensive scours in fluvial deposits must be related as precisely as possible to paleosols developed on laterally equivalent 
mudrocks. Once this has been accomplished, the relative temporal value of an entire alluvial formation, or specific parts of it, can be determined from paleosol maturation sequences, for specific as well as regional geographic areas.

\section{Willwood Maturation Sequence}

Bown (1985) defined five stages of Willwood paleosol maturity (numbered 1 through 5 in order of increasing maturity) based on lateral field relationships of the paleosols. These were distinguished from one another by properties observable in the field, including horizonation, profile development and thickness, color, soil nodule development, mottling, nature of contacts within the profile, and other features (see Bilzi and Ciolkosz, 1977 and Harden, 1982 for field methods used in estimating relative development in modern soils). Recognized as parts of a developmental continuum with no natural breaks, the Willwood maturation stages were originally defined from existing, although arbitrarily picked, field profiles that exemplify landmarks in the paleosol maturation continuum. Their number was limited to five for easy and quick recognition in the field, without recourse to lengthy and costly laboratory procedures.

The Willwood paleosol maturation stages were refined by Bown and Kraus (1987), who used them to define Willwood pedofacies. Kraus (1987) added Stage 0 for alluvial parent materials with no evidence of soil development on them, and to this scheme we add Stage 6 for newly discovered paleosols that appear to be considerably more mature than Stage 5.

One of the single most consistent factors in recognizing maturation stages is the combined thickness of the $A$ and upper B horizons. The upper B horizon is defined as that part of the B lying directly beneath the A horizon and having a color in the grayish purple (5P 4/2), or pale purple $(5 \mathrm{P} 6 / 2)$ to moderate red (5R 4/6) range, and excluding the lower B horizon, which has a lighter red (5R 6/6), orange (10YR $6 / 6)$, or yellow (5Y 7/6) color. The combined $A$ and upper B horizon thicknesses for the Willwood paleosol maturation stages are as follows: Stage $0=0.0 \mathrm{~m}$ Stage $1=0.0-0.2 \mathrm{~m}$; Stage $2=0.5 \mathrm{~m}$; Stage $3=1.1 \mathrm{~m}$; Stage $4=2.5 \mathrm{~m}$; Stage $5=4.2 \mathrm{~m}$; Stage $6=6.0 \mathrm{~m}+$.

Aslan (1990) has shown that Willwood paleosol maturation stage is commonly related directly to, or is a function of, paleosol hydromorphy (relative soil wetness or saturation). Willwood paleosol hydromorphy appears to have resulted from several factors, including position of the developing soil with respect to stream channels its position on the floodplain, and (possibly) climatic and (probably) local drainage variations. Certain Willwood sections evince more hydromorphic properties than others, and Willwood soil wetness affected mammalian distributions (Bown, 1979; Bown and Kraus, 1987; Bown and Beard, 1990); however, relative hydromorphy does not appear to affect the temporal attributes of either mature or immature Willwood paleosols. Accumulative hydromorphy (Bown and Kraus, 1987; equals burial gleization of Retallack, 1991) is a very early diagenetic phenomenon that postdated formation of the affected paleosols.

\section{Temporal Relations of Paleosol Maturation Stages}

Determining the relative amount of time represented by each of the different maturation stages is the most critical aspect of temporally restoring fluvial rocks and, for the Willwood Formation, was achieved by direct field examination of pedofacies packages. As pointed out, pedofacies packages contain essentially contemporaneous paleosols with several vertically stacked immature paleosols close to channel sandbodies and fewer but more mature paleosols more distant to channel sandbodies. Because extensive Willwood exposure allows single pedofacies packages to be traced laterally for great distances, the number of vertically stacked paleosols of one stage could be directly compared to the number of temporally equivalent paleosols of a different stage. For example, field relations show that four Stage 1 paleosols are laterally and temporally equivalent to a single Stage 3 paleosol. Thus a Stage 3 paleosol required about four times as long to form as did a Stage 1 paleosol.

Unfortunately, nowhere have we found a complete pedofacies exposed-one containing a lateral continuum from Stage 0 through Stage 6 paleosols. Even the most extensive badlands rarely exhibit pedofacies segments exceeding a span of two or three paleosol stages. This is because floodplains separating major channels were at least $15 \mathrm{~km}$ wide, considerably more extensive than most areas of continuous unidirectional exposure. Nevertheless, the temporal weights, relative to a Stage 1 paleosol, of the seven Willwood paleosol stages were reconstructed using several different sections in which partial pedofacies are exposed. The relative temporal weight attributed to each maturation stage is shown in Table 1.

In the field, paleosol stage cannot always be determined precisely, despite the intentional coarseness of paleosol stage definitions. For example, the paleosol used to define Stage 3 was subsequently found to be more closely related morphologically to Stage 2 paleosols than those of Stage 4. In the field such intermediates were termed "Stage 2+". Other paleosols for which the more appropriate stage could not be ascertained, but which obviously belong more closely to one adjacent stage or the other, were variously designated stages $0-1,1-2,2-3,3-4$, and $4-5$ accordingly, and their relative temporal weights calculated in proportion. Stage 0 paleosols (time of deposition only, with no hiatal component) are assigned a temporal weight of 0 . This is not meant to imply that Stage 0 (raw soil parent material) took no time to accumulate; rather, it is a figure arrived at from the relative numerical scheme of the maturation stages. Stage 0 has a lesser proportional weight than Stage 1 (or Stage 0-1), which does possess a component of hiatal time. Nevertheless, the deposition time is so exceedingly small compared to even Stage 1 hiatal time that it is, in effect, absorbed in the temporal weight values of the paleosols of all stages. 
TABLE 1-Temporal weights for Willwood Formation paleosol maturation stages; weights are given in units of Stage 1 paleosols.

\begin{tabular}{cc}
\hline \hline Paleosol stage & Temporal weight \\
\hline 0 & 0.0 \\
$0-1$ & 0.5 \\
1 & 1.0 \\
$1-2$ & 1.5 \\
2 & 2.0 \\
$2-3$ & 3.0 \\
3 & 4.0 \\
$3+$ & 5.0 \\
$3-4$ & 6.0 \\
4 & 8.0 \\
$4+$ & 10.0 \\
$4-5$ & 12.0 \\
5 & 16.0 \\
6 & 32.0 \\
\hline
\end{tabular}

\section{Willwood Time Stratigraphic Column}

Master sections and spur sections totaling nearly 3800 $m$ were measured in the Willwood Formation of the southern Bighorn Basin to stratigraphically relate fossil mammal localities. Many of these sections and the fossil localities contained in them were revisited in the 1989 and 1990 field seasons to establish paleosol maturation stages for use in studies of fossil mammal distributions and evolution (see Bown, 1987; Bown and Beard, 1990). As of this writing, 894 fossil mammal localities have been correlated to one another (Bown and Rose, 1987; Bown et al., in press), and the paleosol maturation stages have been determined for 864 localities, of which 719 have known stratigraphic values.

Willwood sections in which most or all sheet sandbodies and mud-floored scours could be converted to equivalent sections of mudrocks containing paleosols were correlated with one another and combined into a single composite master section of $650 \mathrm{~m}$ (from the 0 to $650 \mathrm{~m}$ levels of the Willwood Formation). The resulting section was then divided into 26 intervals, each $25 \mathrm{~m}$ thick, and a maturation index (MI) was determined for each interval. The MI is calculated by summing the temporal weights of all paleosols examined in a particular $25 \mathrm{~m}$ interval and dividing the sum by the total number of paleosols recorded for the interval. For example, in Table 2, the 64 paleosols examined in the 426-450 m interval have a summed temporal weight of 165.5 . Dividing 165.5 by 64 yields a maturation index (MI) of 2.59.

The maturation indices show that relatively immature paleosols increase and relatively mature paleosols decrease upwards through the Willwood section. Marked changes in relative maturity occur at about the $200 \mathrm{~m}$ level and in the interval from about $376-425 \mathrm{~m}$.

The $200 \mathrm{~m}$ horizon and the $376-425 \mathrm{~m}$ interval coincide with biostratigraphic event horizons (times of rapid faunal
TABLE 2-Maturation indices for $25 \mathrm{~m}$ intervals of the Willwood Formation and temporal values at interval tops.

\begin{tabular}{|c|c|c|c|c|}
\hline Interval & $\begin{array}{c}\text { Total } \\
\text { paleosols } \\
\text { examined }\end{array}$ & $\begin{array}{l}\text { Weights/ } \\
\text { paleosols }\end{array}$ & $\begin{array}{c}\text { Matura- } \\
\text { tion } \\
\text { index }\end{array}$ & $\begin{array}{l}\text { Temporal } \\
\text { value } \\
\text { (top of } \\
\text { interval) }\end{array}$ \\
\hline $626-650 \mathrm{~m}$ & 2 & $2 / 2$ & 1.00 & $100 \%$ \\
\hline $601-625 \mathrm{~m}$ & 5 & $22.5 / 5$ & 4.50 & 99.2 \\
\hline $576-600 \mathrm{~m}$ & 8 & $13 / 8$ & 1.63 & 95.8 \\
\hline $551-575 \mathrm{~m}$ & 22 & $49 / 22$ & 2.23 & 94.6 \\
\hline $526-550 \mathrm{~m}$ & 48 & $95.5 / 48$ & 1.99 & 92.9 \\
\hline $501-525 \mathrm{~m}$ & 41 & $129 / 41$ & 3.15 & 91.4 \\
\hline $476-500 \mathrm{~m}$ & 82 & $243.5 / 82$ & 2.97 & 89.0 \\
\hline $451-475 \mathrm{~m}$ & 49 & $118.5 / 49$ & 2.42 & 86.7 \\
\hline $426-450 \mathrm{~m}$ & 64 & $165.5 / 64$ & 2.59 & 84.9 \\
\hline $401-425 \mathrm{~m}$ & 51 & $119.5 / 51$ & 2.34 & 82.9 \\
\hline $376-400 \mathrm{~m}$ & 23 & $96.5 / 23$ & 4.20 & 81.1 \\
\hline $351-375 \mathrm{~m}$ & 44 & $208.5 / 44$ & 4.74 & 78.0 \\
\hline $326-350 \mathrm{~m}$ & 28 & $162.5 / 28$ & 5.80 & 74.4 \\
\hline $301-325 \mathrm{~m}$ & 7 & $45 / 7$ & 6.43 & 70.0 \\
\hline $276-300 \mathrm{~m}$ & 20 & $121.5 / 20$ & 6.08 & 65.1 \\
\hline $251-275 \mathrm{~m}$ & 12 & $74 / 12$ & 6.17 & 60.5 \\
\hline $226-250 \mathrm{~m}$ & 5 & $16 / 5$ & 3.20 & 55.8 \\
\hline $201-225 \mathrm{~m}$ & 5 & $27.5 / 5$ & 5.50 & 53.3 \\
\hline $176-200 \mathrm{~m}$ & 18 & $127.5 / 18$ & 7.08 & 49.2 \\
\hline $151-175 \mathrm{~m}$ & 11 & $76.5 / 11$ & 6.95 & 43.8 \\
\hline $126-150 \mathrm{~m}$ & 23 & $126 / 23$ & 5.48 & 38.5 \\
\hline $101-125 \mathrm{~m}$ & 16 & $149.5 / 16$ & 9.34 & 34.3 \\
\hline $76-100 \mathrm{~m}$ & 12 & $82 / 12$ & 6.83 & 27.2 \\
\hline $51-75 \mathrm{~m}$ & 5 & $42 / 5$ & 8.40 & 22.1 \\
\hline $26-50 \mathrm{~m}$ & 24 & $207.5 / 24$ & 8.65 & 15.7 \\
\hline $1-25 \mathrm{~m}$ & 8 & $96 / 8$ & 12.00 & 9.1 \\
\hline
\end{tabular}

Temporal values calculated from Equation 1 and the maturation index for each interval.

turnover) in the record of Willwood fossil vertebrates. This correlation suggests a direct link between biotic/evolutionary events and concurrent changes in the paleopedologic (and therefore sedimentologic) regime. The $200 \mathrm{~m}$ level is the boundary between the "lower Gray Bull" and "middle Gray Bull" faunas of Granger (1914), and the 376$425 \mathrm{~m}$ interval separates Granger's "middle Gray Bull" faunas from those of his "upper Gray Bull". Schankler (1980) coined the term Biohorizon A for the event at 200 $\mathrm{m}$, and Biohorizon $\mathrm{B}$ for a second presumed horizon at 380 $\mathrm{m}$. The two biohorizons separate Schankler's lower and upper Haplomylus-Ectocion range zones and the upper Haplomylus-Ectocion Range Zone from his Bunophorus Interval Zone, respectively. Schankler recognized a third biostratigraphic event horizon, Biohorizon $\mathrm{C}$, at the 530 $\mathrm{m}$ level-a horizon he judged to mark the boundary between the Bunophorus Interval Zone and his lower Heptodon Range Zone. In Granger's (1914) usage, Biohorizon $\mathrm{C}$ is the boundary between beds yielding the "Gray Bull" fauna and those producing the Bighorn "Lysite" fauna (see also Wood et al., 1941). 


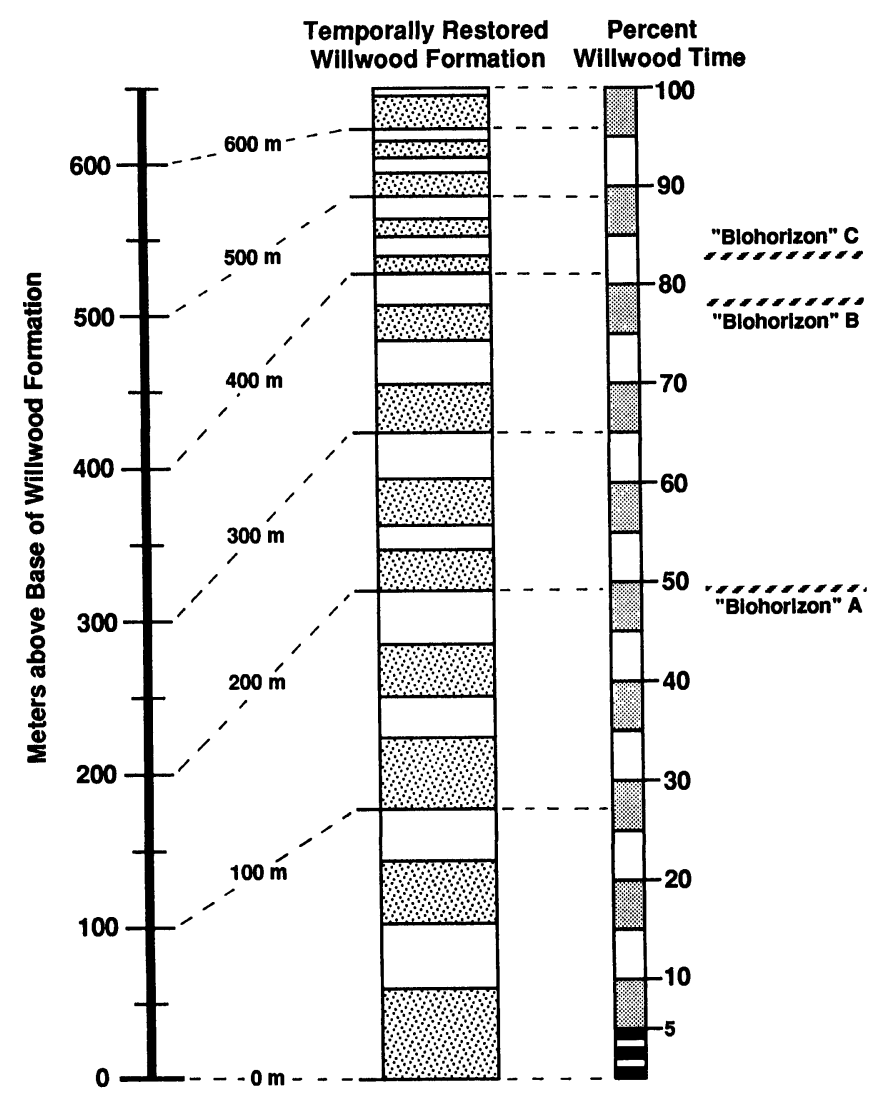

FIGURE 3-Diagram showing Willwood Formation meter levels (left column) and their translation into a time-stratigraphic column (middle column). Temporal values for each $25 \mathrm{~m}$ interval (right column) indicate what percent of total Willwood time has elapsed when a particular stratigraphic level was deposited. Note temporal versus stratigraphic positions as exemplified by Biohorizon A ( $200 \mathrm{~m}$ level out of $650 \mathrm{~m}$ total stratigraphically, but at approximately one-half of formation time). Temporal values are given in Table 2 and are based on Equation 1 and the maturity indices.

The relative temporal resolution of Willwood rocks and sedimentologic events and further refinement of biotic and evolutionary events was accomplished from the maturity indices. The maturation index is a measure of the relative time that it took to create a particular $25 \mathrm{~m}$ interval. Consequently, the proportion of Willwood time that is represented by each interval of $25 \mathrm{~m}$ can be determined by dividing the MI for the interval by the sum of the maturation indices for all intervals in the formation. More importantly, the percentage of the total time represented by the $650 \mathrm{~m}$ Willwood section (temporal value $=\mathrm{TV}$ ) that has already elapsed when a particular stratigraphic level (SL) is deposited can be calculated using the formula:

$$
\mathrm{TV}=\frac{\sum_{\mathrm{i}=0-25 \mathrm{~m}}^{\mathrm{n}-1 \text { interval }} M I_{i}+\left(\mathrm{SL} / 25 \times\left(\mathrm{MI}_{\mathrm{n}}\right)\right) \times 100}{\mathrm{MI}_{\text {total }}}
$$

where MI is the maturation index for a particular $25 \mathrm{~m}$ interval; $\mathrm{n}=$ the $25 \mathrm{~m}$ interval in which the stratigraphic level (SL) of interest occurs; and MI (total) = the sum of the maturation indices for the entire $650 \mathrm{~m}$ Willwood section. As an example, the temporal value of the $90 \mathrm{~m}$ level in the Willwood Formation is:

$$
\mathrm{TV}=\frac{\begin{array}{l}
(12.00+8.65+8.40) \\
+((90-75) / 25 \times(6.83)) \times 100
\end{array}}{(131.67)}=25.2 \%
$$

\section{WILLWOOD FORMATION SEDIMENT ACCUMULATION RATES}

By representing each $25 \mathrm{~m}$ interval by its temporal value rather than by its thickness, a restored time-stratigraphic column is generated for the Willwood Formation at a resolution of $25 \mathrm{~m}$ (Fig. 3, middle column) and this offers the key to evaluating changes in Willwood net sediment accumulation rates through time. The time-stratigraphic reconstruction demonstrates that the Willwood Formation of the southern Bighorn Basin is naturally divisible into three units $(0-200 \mathrm{~m}, 201-400 \mathrm{~m}, 401-600 \mathrm{~m})$ that internally show relatively constant rates of sediment accumulation. However, the three differ from one another in paleosol maturity, and thus accumulation rates. The lower $200 \mathrm{~m}$ of the Willwood Formation is typified by relatively mature paleosols, each of which required considerable time to form; the middle $200 \mathrm{~m}$ of the formation is characterized by less mature paleosols that required somewhat less time to form, and the upper $200 \mathrm{~m}$ is dominated by immature paleosols that represent an even smaller percentage of Willwood Formation time. In fact, the time-stratigraphic column shown that the lower $200 \mathrm{~m}$ of the formation required slightly less than half of the total time represented by the Willwood column from $0-650 \mathrm{~m}$.

The paleosol data indicate relatively low rates of sediment accumulation in the southern Bighorn Basin at the onset of Willwood deposition, and a general increase in these rates through time (Fig. 4, right column). That this increase was relatively constant is shown by the more or less continuous decline in maturation indices through time; however, there are significant punctuations of this trend. These occur in the 75-150 m, 200-250 m, 375-425 m, and $600-625 \mathrm{~m}$ intervals. Reference to the biostratigraphic record of the Willwood Formation shows that these intervals coincide with paleobiologic events: $200 \mathrm{~m}$ is Schankler's (1980) Biohorizon A; and $380 \mathrm{~m}$ is Schankler's Biohorizon B. The $75-150 \mathrm{~m}$ and $600-625 \mathrm{~m}$ intervals are more complicated and are addressed further in a following section, but paleosol data now indicate a clear relationship between paleosol maturity (and sediment accumulation rate) and paleobiologic events of biostratigraphic significance.

A qualification to the foregoing discussion is the relationship between Willwood sediment accumulation rates and geographic position within the Bighorn Basin. The Bighorn Basin is an asymmetrical syncline with the steeper limb on the west. On the eastern side, Willwood rocks dip westward toward the basin axis and, in the southern part of the basin, the older part of the formation is exposed 
only along the eastern and extreme southern basin margins. The youngest Willwood rocks are preserved only near the basin axis, on and west of which they overlap truncated Fort Union (Paleocene) and older rocks with pronounced angular unconformity (Hewett, 1926; Bown, 1982). Therefore, the character of younger Willwood strata in the eastern Bighorn Basin is not known, nor is that of the lower part of the Willwood Formation along the basin axis. What is known is that paleosol maturities (and maturation indices) decrease upward through the known Willwood section. Consequently, the general paleosol maturity decreases westward where the strata are younger. Maturity also decreases in the direction of the basin axis, in part, because net sediment accumulation rates increase near the axes of aggrading basins (see Kraus, 1980, 1987, on relations of axial Willwood paleosols to sandbodies in the Clark's Fork region of the northern Bighorn Basin). In addition, stream systems tend to locate in areas of more rapid subsidence (e.g., Bridge and Leeder, 1979), commonly near to basin axes, and relatively more immature paleosols develop proximal to stream channels. Nonetheless, with these constraints in mind, supplemented with knowledge that the Bighorn Basin structural axis migrated westward through time (e.g., Gingerich, 1983), any relatively complete section of Willwood rocks in the southern Bighorn Basin should contain a resolvable, and similar, record of sediment accumulation rates.

\section{PALEOSOLS AND MAMMALIAN FAUNAL PATTERNS, WILLWOOD FORMATION}

Bown (1987) and Bown and Beard (1990) examined the relative distributions and abundances of sympatric species of fossil mammals with respect to their occurrences in paleosols of different maturities distributed across two richly fossiliferous pedofacies suites at about the $442 \mathrm{~m}$ and $546 \mathrm{~m}$ levels of the Willwood Formation. Those studies determined that the abundances of certain sympatric species relative to each other are related to the maturity of the paleosol from which their fossils were obtained. Because paleosol maturity is determined by proximity to stream channels, the resulting record of relative abundances of species from particular paleosols is a measure of the preferences of the animals during life for more proximal or more distal environments (relative to stream channels) on the alluvial plain. Such preferences were almost certainly controlled by the patterns of then extant vegetation across the pedofacies as well as other local environmental factors such as soil dampness. Relative paleosol maturity (and corresponding proximal, intermediate, and distal positions with respect to streams) were also demonstrated to be important factors governing fossil abundance and state of preservation. In general, proximal (immature) paleosols contain fewer fossils per paleosol but yield a higher proportion of relatively complete remains than distal (more mature) paleosols. This phenomenon is controlled by differing short-term net sediment accumulation rates across the pedofacies-higher rates closer to channels increase the likelihood that remains will be bur-

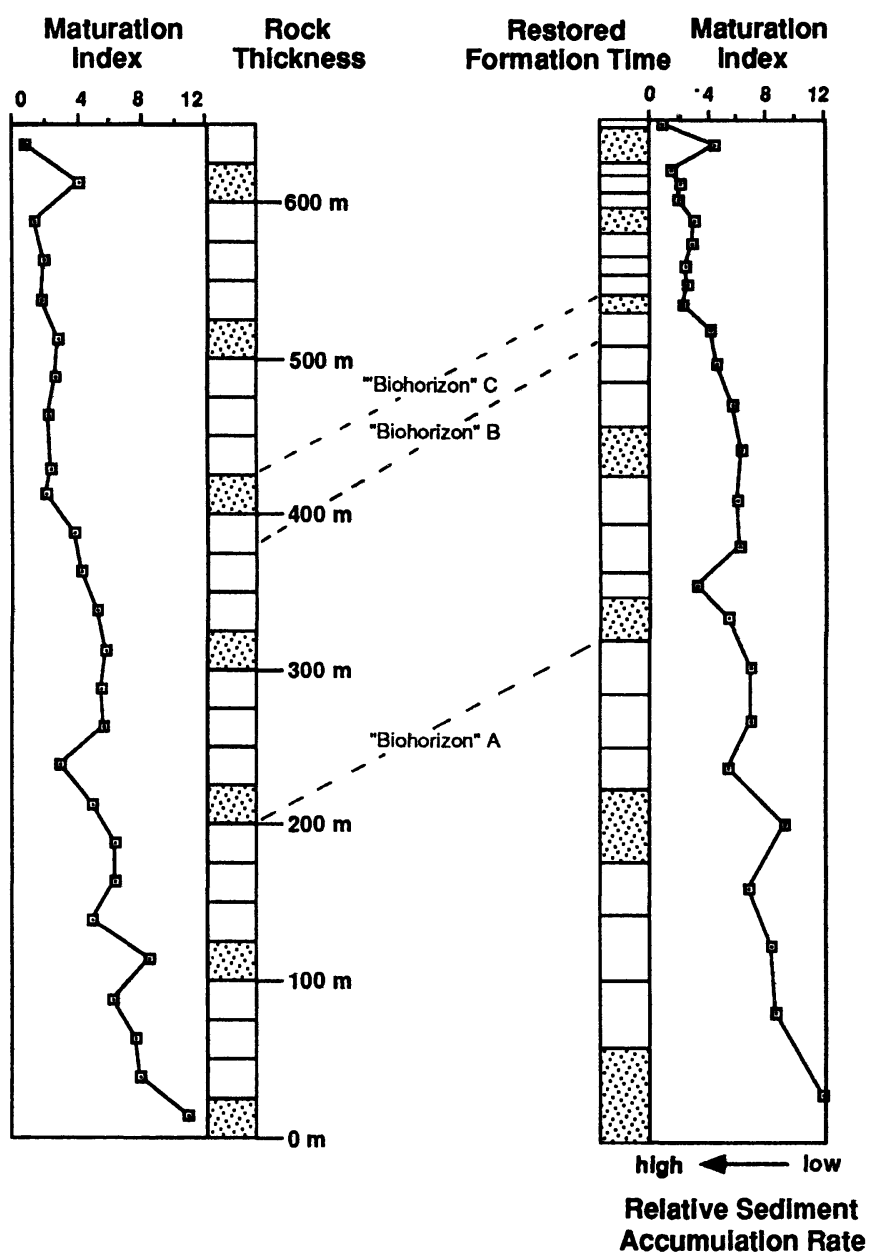

FIGURE 4-Diagram showing maturation indices (MI) for each $25 \mathrm{~m}$ interval of the Willwood Formation plotted against Willwood rock thickness (left column) and against the time-stratigraphic column (right column). The right column provides an estimate of relative Willwood sediment accumulation rates in relative time instead of meter intervals.

ied more rapidly, prior to much scavenging or other destructive factors, but allowing less time for large quantities of bones of many individuals to accumulate in the soil.

But what of the relationship of paleosol maturity to large temporal scale patterns of mammalian distribution and evolution? If the distributions of at least some sympatric species of extinct mammals are directly related to paleosol maturity, geographic position on floodbasins, and shortterm net sediment accumulation rates, how might these effects by distributed through time in a temporally restored formation? Unfortunately, the sheer magnitude of collections of tens of thousands of Willwood fossil mammals from hundreds of widely scattered localities renders curation, adequate alpha-level taxonomy, and precise stratigraphic and paleopedogenic correlation quite formidable, requiring years of basic research. Despite such obstacles, enough is known in general about the distribution and evolution of Willwood mammals to offer some 


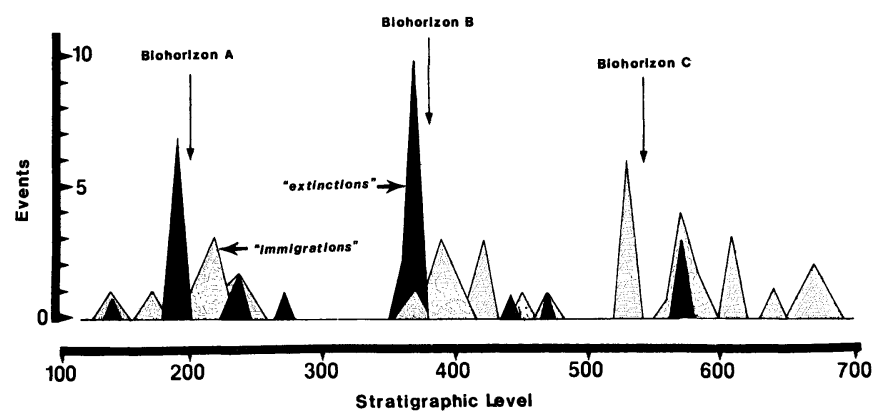

FIGURE 5-Frequency of events of extinction (black shading) and immigration (stippled shading) of Willwood mammals plotted against meter levels above base of the Willwood Formation in the SchanklerWing section (re-drawn from Schankler, 1980, fig. 4).

correlations. These support close and direct relationships among sedimentary-tectonic changes, pedofacies evolution, and evolving patterns of mammalian faunal organization.

\section{Willwood Faunal Turnovers}

Schankler's $(1980,1981)$ faunal zonation of the Willwood Formation was, at the time it appeared, the most comprehensive biostratigraphic study of a Paleogene sequence and its mammalian fauna. Utilizing biostratigraphic data for 131 species of fossil mammals from 243 localities, Schankler identified three faunal breaks in the record of Willwood mammal evolution; to recapitulate, these he termed Biohorizon A (200 m level), Biohorizon B (380 m level), and Biohorizon C (530 m level). As originally defined, Biohorizon A is characterized by the disappearance (="extinction" as used by Schankler) of eight species and the appearance (="immigration" of Schankler) of seven species of early Eocene mammals. Biohorizon B records the disappearance of 13 species and the appearance of 9 others, and Biohorizon $\mathrm{C}$ of 3 disappearances and 16 appearances.

As was certainly recognized by Schankler, the faunal turnover events do not define horizons; rather, they are intervals and the meter levels accorded each horizon were arbitrarily established at meter levels immediately following the most significant event of each "biohorizon" (7 disappearances at Biohorizon A, 10 disappearances at Biohorizon B, and 6 appearances at Biohorizon $\mathrm{C}-$ see Schankler, 1980, fig. 4; Fig. 5, this paper). Moreover, Schankler's grouping of the appearances and disappearances used in characterizing the biohorizons is odd. For example, the three disappearances between $220 \mathrm{~m}$ and 270 $\mathrm{m}$ are included with disappearances making up Biohorizon B (at $380 \mathrm{~m}$ ) rather than Biohorizon A (at $200 \mathrm{~m}$ ). Two disappearances in the $430-470 \mathrm{~m}$ interval are attributed by Biohorizon C (at $530 \mathrm{~m}$ ), even though they might with equal facility be assigned to Biohorizon B. In Schankler's scheme of the distribution of disappearance and appearance events for each biohorizon, the record of disappearances began with but one or two events and culminated in the most significant disappearance event. That is to say, the biohorizon boundaries are drawn after the most significant disappearance event in the cases of Biohorizons $\mathrm{A}$ and $\mathrm{B}$, and following the most important appearance event for Biohorizon C. By this arrangement (and it is only an arbitrary solution), Schankler is correct in recording that Biohorizons A and B are typified by disappearances and (in both number and magnitude) the hallmark of Biohorizon $\mathrm{C}$ is appearance. This scenario is essentially the same as that produced by simply dividing the stratigraphically arranged event data into the three obvious intervals separated by gaps in disappearance and appearance events (about 130-270 m, 380-470 m, and 520-680 m; see Fig. 4).

In summarizing the results of his studies of Willwood biohorizons, Schankler (1980, p. 108) stated that:

“The near synchrony of immigration-'extinction' events at Biohorizons A and B suggests changing climatic or ecological conditions as a causative factor, whereas the period of immigration beginning at Biohorizon $\mathrm{C}$ with little or no apparent 'extinction' raises the possibility that breakdown of a physical barrier to immigration was responsible."

Viewing Willwood faunal turnover and coeval pedofacies evolution against a restored Willwood temporal framework indicates a similar but somewhat more complicated solution.

In stratigraphically correlating Willwood fossil mammal localities, three separate spur sections were measured from the base to the top of the Elk Creek Rim (Bown, 1980, fig. 1). The Elk Creek Rim separates the drainages of Elk and Fifteenmile creeks in the central part of the southern Bighorn Basin and contains exposures pivotal to correlating faunas of the lower and upper parts of the Willwood Formation. Schankler placed the first post-Biohorizon $\mathrm{C}$ faunas at localities at and above the level of Yale Peabody Museum locality 227 (Y-227), near the top of the rim at $530 \mathrm{~m}$ in his section (measured by Schankler and Scott Wing); however, Y-227 occurs $73 \mathrm{~m}$ lower, at $457 \mathrm{~m}$, in Bown's section. In addition, Schankler correlated Y-227 with the exceptionally rich locality Y-45, situated about 11-12 km to the south-southeast. The Schankler-Wing section also places Y-226 at $410 \mathrm{~m}$ and Y-269 at $420 \mathrm{~m}$, localities placed at $385 \mathrm{~m}$ and $394 \mathrm{~m}$, respectively, in the Bown section. The Schankler-Wing section also shows 120 $\mathrm{m}$ separating Y-226 and Y-227, and $110 \mathrm{~m}$ separating Y-269 and Y-227; the Bown section shows them separated by 72 $\mathrm{m}$ and $63 \mathrm{~m}$, respectively. Three additional sections between Y-226 and Y-227 were measured by Bown, yielding values of $70 \mathrm{~m}, 65 \mathrm{~m}$, and $68 \mathrm{~m}-50-55 \mathrm{~m}$ less than in the Schankler-Wing section. Consequently, meter levels reported by Schankler (1980) for localities at or above 530 $\mathrm{m}$ (all above the Elk Creek Rim in the Schankler-Wing section) have been revised downward by $73 \mathrm{~m}$ (Y-227 at $457 \mathrm{~m}$ rather than $530 \mathrm{~m}$ ). This revision leaves an unresolved measurement difference of about $25 \mathrm{~m}$ for localities between Y-226 and Y-227, and the revised total thickness of the Willwood Formation is therefore about $700 \mathrm{~m}$.

What makes this stratigraphy important is that $530 \mathrm{~m}$ 
is Schankler's level for Biohorizon C, the putative boundary between the old "Gray Bull" and Bighorn "Lysite" faunas of Granger (1914), and what makes it interesting is that $530 \mathrm{~m}$ minus $73 \mathrm{~m}$ is $457 \mathrm{~m}$, a figure well with the upper limit of the stratigraphic range of events defining Biohorizon B (380-470 m). Furthermore, the Bown section places Y-45 (viewed by Schankler as a pivotal basal Heptodon Range Zone site) at $470 \mathrm{~m}$. Numerous fossil localities now show that the lowest known occurrences of such "Lysite" taxa as Absarokius and Heptodon are at $425 \mathrm{~m}$ and $430 \mathrm{~m}$, respectively (the $425 \mathrm{~m} \mathrm{Absarokius} \mathrm{is} \mathrm{A.} \mathrm{metoecus,}$ a species unknown at the time of Schankler's study; $A$. abbotti, believed by him to be a Biohorizon B immigrant, is first known at $455 \mathrm{~m}$ ).

\section{Faunal Events and Willwood Paleosols}

Figure 6 illustrates faunal turnover events recognized by Schankler (1980) with the addition of formation boundary disappearances, and with the position of Biohorizon $\mathrm{C}$ corrected to $420 \mathrm{~m}$ (the first appearance of Absarokius). In addition to faunal events (disappearance, appearance), the maturity indices of paleosols in each $25 \mathrm{~m}$ interval of the Willwood Formation are graphed on the $\mathrm{x}$-axis. More importantly, the y-axis now records temporally-weighted meter levels (or temporal values) for the Willwood Formation instead of simple meter levels (see Fig. 3, central column), allowing faunal turnover events and pedofacies evolution to be viewed against a framework of restored formation time; i.e., pedogenic and faunal events are more accurately related to one another in intraformational time.

Three major episodes of faunal turnover are evident. The earliest (at $0 \mathrm{~m}$ ) is marked by disappearance of 14 species at the land-mammal age boundary between the Clarkforkian (Rose, 1981) and the Wasatchian (Wa0 stage of Gingerich, 1989). Appearances at the land-mammal age boundary are not graphed because their stratigraphic distribution has not yet been resolved in the southern Bighorn Basin (although more than 16 species are involved in the initial part of this profound appearance event). The second major faunal turnover is that from $140-270 \mathrm{~m}$, flanking Schankler's Biohorizon A, and the third spans the 380$570 \mathrm{~m}$ interval and combines undifferentiated disappearance and appearance events of biohorizons B and C.

In Schankler's stratigraphy, the meter-level differences between biohorizons $\mathrm{B}$ and $\mathrm{C}$ were $19.4 \%$ of his $773 \mathrm{~m}$ Willwood thickness $(530-380 \mathrm{~m} / 773 \mathrm{~m}=19.4 \%)$. Recognition of Biohorizon $\mathrm{C}$ faunas at $425 \mathrm{~m}$ in a $700 \mathrm{~m}$ thick Willwood section reduces this figure to $6.4 \%$, and the temporal difference calculated using temporal values from this study is only $4 \%$ of a $700 \mathrm{~m}$ thick Willwood Formation. In this more accurate temporal context, it is clear the biohorizons $B$ and $C$ record a single, but very important, episode of Willwood faunal turnover (here termed B-C), with Biohorizon $B$ largely marking the disappearances, and Biohorizon $\mathrm{C}$ principally the appearances. As at Biohorizon A, appearances largely follow disappearances and, in a considerable reversal of earlier views, Biohorizon A events

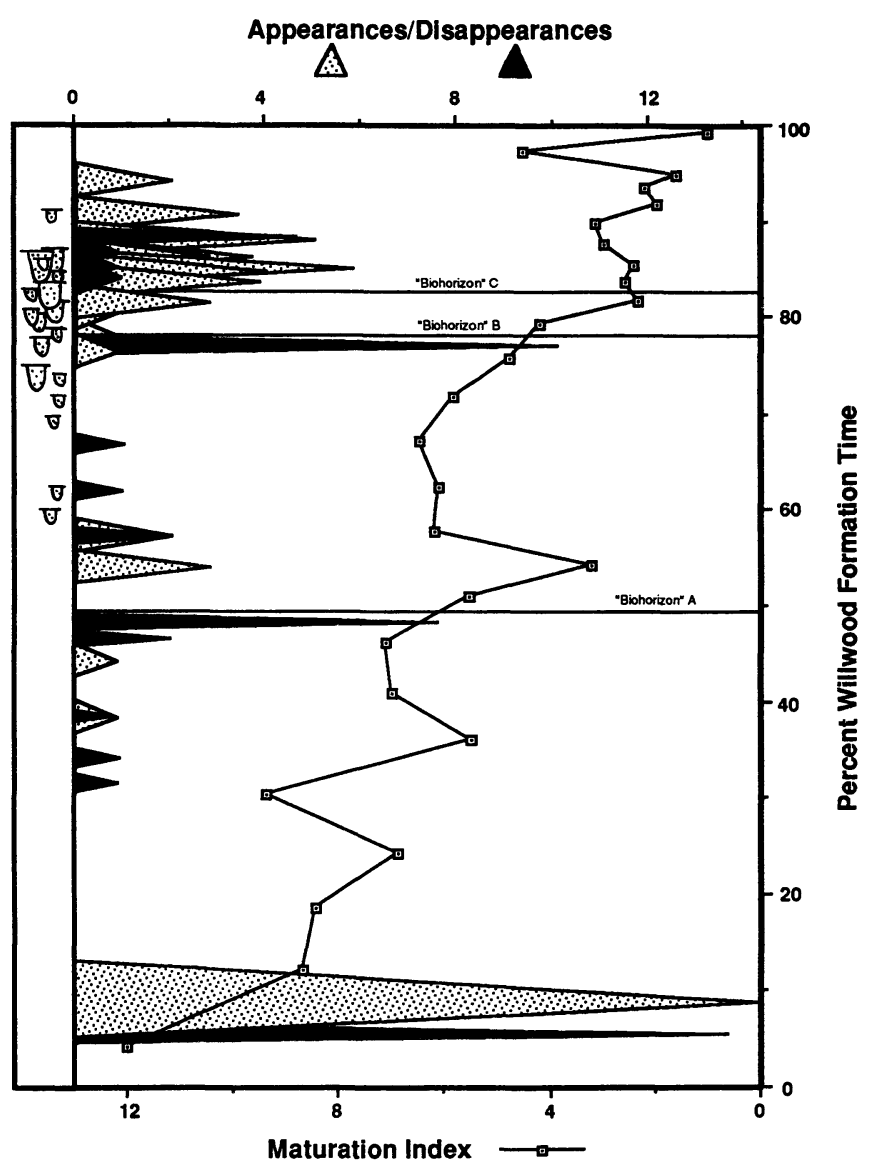

FIGURE 6-Occurrence of Willwood Formation faunal events plotted against percent of total Willwood Formation time (temporal value). Faunal data include information gained since the study of Schankler (1980), as well as an estimate of immigrant species at the WaO event. Paleosol maturity indices (open squares) are also plotted for each temporally restored $25 \mathrm{~m}$ interval. Note the near temporal coincidence of Biohorizon $\mathrm{C}$ with Biohorizon B, and greater temporal spread of Biohorizon A with respect to combined Biohorizon B-C. See text for further discussion. The far left column shows the occurrence of mudfilled scours in the Willwood Formation.

occupy nearly twice as much formation time as Biohorizon B-C events combined (35.3\% versus about $19 \%$ ). Moreover, Biohorizon A, at a stratigraphic level of $28.6 \%$ of formation thickness $(=200 \mathrm{~m} / 700 \mathrm{~m})$, is actually almost exactly in the middle of Willwood Formation time (Fig. $6)$.

\section{Structural Controls}

The Willwood Formation is distinguished from the underlying Fort Union Formation by a major increase in paleosol maturity (maturation indices rise from 0.5 to 12.0 ) that is succeeded by a gradual and more or less continuous decline in maturity, at least through to the $650 \mathrm{~m}$ level of the Willwood Formation (Fig. 6). Figure 7 shows that paleosol hydromorphy also varied through Willwood time, with a significantly lower incidence of hydromorphic pa- 
leosols in the second half of Willwood time. These formation-scale changes probably resulted from allocyclic factors including changes in tectonic activity and climate.

The contact between the Fort Union and Willwood formations in the southern Bighorn Basin is believed to correspond to the Paleocene-Eocene boundary. The Paleocene-Eocene break is also the time at which regional climates became warmer and drier (Hickey, 1980; Wing, 1980; Wolfe, 1989); in fact the early Eocene is believed to have been the warmest part of the Tertiary (e.g., Molnar and England, 1990; McGowran, 1990). The earliest Eocene was also a time of tectonic activity in the southern part of the Bighorn Basin with rise of the Owl Creek Mountains. The Owl Creeks are southerly overthrust antiform mountains bordering the south-central and southwest margins of the Bighorn Basin. In the adjacent Wind River Basin to the south, the principal structural elevation of the Owl Creek Mountains is recorded in the lower Eocene Indian Meadows and Wind River Formations (Love, 1939; Keefer and Troyer, 1956; Keefer, 1965). The Indian Meadows Formation contains a late early Wasatchian mammal fauna (Love, 1939, Winterfeld, 1986) and is capped by conglomerates rich in Paleozoic limestone clasts. An angular unconformity separates the Indian Meadows Formation from the overlying Wind River Formation, which yields faunas of middle and late Wasatchian, Gardnerbuttean, and early Bridgerian age (later early Eocene-earliest middle Eocene; Guthrie, 1967, 1971; Stucky, 1984a, b) and locally contains granitic-clast conglomerates in its lower part. The upper Indian Meadows and lower Wind River conglomerates therefore record the progress of later early Eocene unroofing of Paleozoic and Precambrian rocks of the Owl Creek Mountains, concomitant with their maximum structural elevation.

In the south-central Bighorn Basin, this tectonic activity may have been responsible for the gradual increase in sediment accumulation rates through Willwood time. Furthermore, the change to less hydromorphic paleosols in the upper part of the Willwood Formation probably reflects the development of a partial rain shadow in the southern Bighorn Basin in response to rise of the Owl Creek and southern Bighorn Mountains. This idea was originally put forth by Bown (1979) and Bown and Kraus (1981a), although with little rigorous documentation of upsection changes in hydromorphy.

In addition to the gradual formation-scale changes in maturity and hydromorphy, three significant changes in paleosol maturity are also evident in Figure 6 and these roughly correspond to the three major episodes of faunal turnover-Wa0, Biohorizon $\mathrm{A}$, and combined biohorizons B-C. If faunal turnover events surrounding Biohorizon A were significant, those recorded by $\mathrm{Wa} 0$ or Biohorizon $\mathrm{B}-\mathrm{C}$ were catastrophic. The initial keys to unraveling what phenomena might have triggered the significant faunal events lie in the record of paleosol changes through time.

The three faunal events occur under different conditions of overall paleosol maturity and hydromorphy; however, they all occur at times of significant changes in maturity (Figs. 6 and 7). As discussed, soil maturity is controlled by sediment accumulation rate and that rate also influences the depositional environment. Rapid rates of sediment accumulation (associated with immature paleosols) typically result in frequent channel avulsion and thus relatively unstable floodplains (e.g., Smith et al., 1989). In contrast, relatively low sediment accumulation rates (associated with mature paleosols) suggest infrequent channel avulsions and thus more stable floodplain environments.

All three faunal events are characterized by disappearances that correlate broadly with a peak followed by a relatively rapid decline in paleosol maturity ( $\mathrm{Wa} 0$ event) or with a plateau in maturity followed by the advent of a rapid decline in maturity (biohorizons A and B-C, although the former shows greater fluctuation in maturity prior to the decline; Fig. 6). This suggests that disappearances correspond to times when initially stable floodplain environments are growing less stable. That the disappearances occur at maturity peaks or immediately after a maturity decline has set in (but not when the decline has reached its nadir) probably indicates that the mammals responded relatively quickly to changing floodplain conditions whereas the soils, which record environmental conditions over some period of time, lagged somewhat behind. Immigrations, on the other hand, correspond well with lows in paleosol maturity, following rather sharp declines. All three turnover events show major appearances immediately following a pause in the decline in maturity and, almost invariably, following disappearances. This correlation indicates that new groups were able to exploit the more rapidly changing floodplain conditions.

Changes in paleosol hydromorphy also appear to have influenced both biohorizons A and B-C. The first Biohorizon A faunal events occur at $140 \mathrm{~m}$ and the last at $270 \mathrm{~m}$. This interval occurs within a period marked by hydromorphic (relatively saturated) paleosols, which begins at a temporal value of about $22 \%$, peaks at about $34 \%$, shows a fluctuation in the incidence of hydromorphic paleosols, and ends in a nadir for the lower part of the Willwood Formation at about $60 \%$ of total Willwood time (about the $260 \mathrm{~m}$ level). The combined Biohorizon B-C interval was also heralded by a peak (following a rapid rise) in paleosol hydromorphy. Once paleosol hydromorphy had stabilized at a new low level for the formation (at $85 \%$ of total Willwood time), this parameter remained low but continued to fluctuate considerably (Fig. 7).

In summary, Schankler (1980) attributed Biohorizon A events to ". . changing climate or ecological conditions". In contrast, Badgley and Gingerich (1988) concluded that, in the Clark's Fork area of the northern Bighorn Basin, Biohorizon A may be an artifact of sampling because of the high correlation there of sample size and species richness. Sample size is always a problem in establishing the nature and significance of biostratigraphic horizons; however, rich samples in the central Bighorn Basin indicate that sample size was probably not a significant factor here. Furthermore, even Badgley and Gingerich admitted that changes in sample size are themselves indicators of possible significant environmental changes that could produce 
faunal events such as Biohorizon A. In fact, they observed that the most dramatic decline in sample size in the Clark's Fork area coincides with Biohorizon A, suggesting that environmental conditions may have played an important role there also.

Both biohorizons A and B-C are clearly related to (1) decrease in paleosol maturity, (2) increase in net sediment accumulation rate, and (3) increase in paleosol hydromorphy. Ecologic shifts in fossil mammals and plants are compatible with changes leading to a high incidence of hydromorphic soils because the plants are rooted in the soils and the distributions of mammals are controlled ultimately by those of plants. Willwood palynological studies show changes in the abundance of pollen taxa that Farley $(1989,1990)$ related to the relative lateral positions of the samples, mirroring the mammalian lateral abundance changes controlled by paleosol type recorded by Bown (1987) and Bown and Beard (1990). Additionally, changes in maturity and sediment accumulation rates indicate a change to more frequent channel avulsion and thus greater instability of the floodplain environments inhabited by the mammals. This is consistent with Schankler's interpretation of the origin of Biohorizon A.

The factors responsible for the periods of more rapid decrease in paleosol maturity and hydromorphy within the more gradual, formation-scale declines in those two parameters are uncertain. The more rapid decreases in paleosol maturity indicate that sediment accumulation rates and thus the rates of basin subsidence accelerated. We speculate that increases in those rates are related to tectonic pulses in the development of the surrounding Owl Creek and southern Bighorn Mountains. In addition, Biohorizon B-C is associated with the occurrence of two other sedimentologic features, lenticular carbonaceous mudrocks and abundant mudstone-filled scours (Fig. 6). Both of these features are common in the mid to upper part of the Willwood section (from about 65 to $85 \%$ of Willwood time). Wing (1984) suggested that lenticular, in contrast to tabular, carbonaceous units develop in abandoned channels and thus indicate frequent channel avulsion. Likewise, the mudstone-filled scours probably represent abandoned channels (and also frequent avulsion) because they are usually developed adjacent to a channel sandbody. Frequent channel avulsion is consistent with the rates of sediment accumulation for this part of the section, which are among the most rapid for the formation. An unresolved question is why neither feature continues higher in the Willwood section, where paleosols predict that accumulation rates were the highest for the formation.

The Wa0 event appears to have occurred under more unusual conditions than the other two faunal turnovers. The introduction of $\mathrm{Wa} 0$ mammals characterizes the Clarkforkian-Wasatchian land-mammal age boundary, which is generally thought to mark the Paleocene-Eocene boundary in the Bighorn Basin (Rose, 1981; Gingerich, 1989). As discussed above, this boundary corresponds to a major climatic change from cooler and drier to relatively warm and wet conditions. The depleted faunas of the later Clarkforkian (the Phenacodus-Ectocion zone) are real in

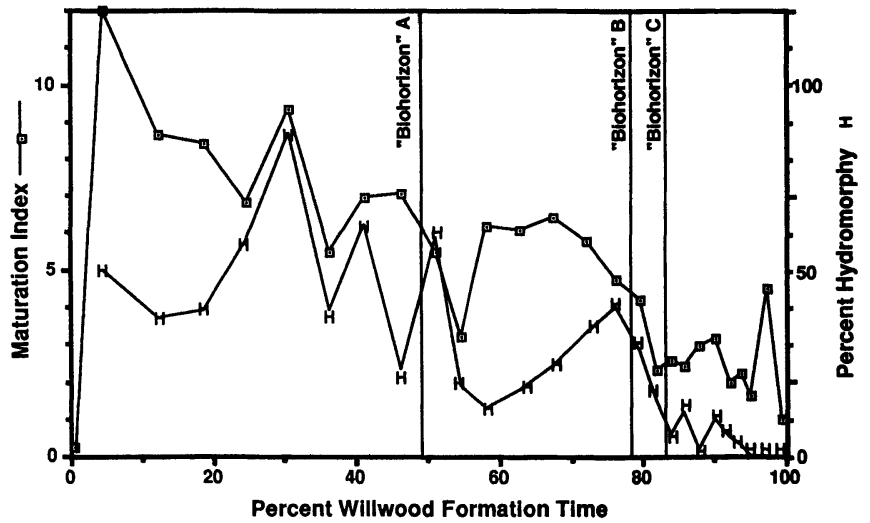

FIGURE 7-Paleosol hydromorphy $(\mathrm{H})$ and maturity indices (open squares) for each $25 \mathrm{~m}$ interval plotted against percent of total Willwood Formation time (temporal value). See text for further discussion.

paleoecological terms and record Paleocene climatic deterioration prior to the more equable conditions of the earliest Eocene. The late (but not latest) Clarkforkian was a time of rapid sediment accumulation, whereas $\mathrm{Wa} 0$ corresponds to a rapid increase in paleosol maturity and thus lower sediment accumulation rate.

The Wa0 event also differs from the other two faunal turnovers in that it appears to have occurred relatively quickly, with almost coincident disappearance and appearance events. The disappearances follow a period of unusually mature paleosols, which in turn lie directly above exceptionally immature and hydromorphic paleosols in the Fort Union Formation.

Retallack (1986) observed that several declines in the diversity of Eocene-Oligocene mammals in South Dakota coincide with significant changes in paleosol maturity. In this example, the paleosol and faunal changes accompanied major episodes of erosional downcutting and climatic changes were believed to be responsible for the physical and biologic events.

\section{SUMMARY}

Paleosols in the Willwood Formation can be assigned to seven different maturation stages and the relative times of development for each stage were determined from pedofacies relationships. Based on the paleosol temporal relations, a time-stratigraphic column was constructed for a composite stratigraphic section of the Willwood Formation in which channel sandbodies or strata removed by scouring were replaced by laterally equivalent paleosols.

The time-stratigraphic reconstruction shows that sediment accumulation rates gradually increased through Willwood time, whereas both overall paleosol maturity and paleosol hydromorphy decreased. Structural elevation of the Owl Creek Mountains in early Eocene time is believed to have caused these trends. In addition, three sharp changes in maturity and hydromorphy (times of mature paleosols followed by sharp declines in maturity) interrupt the gradual trends. These are attributed to tectonic pulses, 
periods when the rate of basin subsidence abruptly increased. Each marked change in paleosol maturity and hydromorphy coincides with a significant episode of faunal turnover. All three episodes occur at times when floodplains were showing signs of instability or frequent avulsion, as indicated by a dominance of immature paleosols following a period of paleosol maturity, In addition, the oldest faunal turnover occurs at the Paleocene-Eocene boundary and probably reflects, at least in part, climatic warming during Eocene time.

Paleosol maturity and time-stratigraphic reconstruction are important for shedding additional light on a number of aspects of the vertebrate fossil record of the Willwood Formation, including: 1) mammalian evolutionary style and tempo, 2) incidences of new or rare taxa, and 3) ecological "re-entry" of mammalian taxa. The model of pedofacies-derived time-stratigraphic reconstruction presented here should be applicable to other alluvial formations once paleosol maturation sequences are established for their respective pedofacies assemblages.

\section{ACKNOWLEDGMENTS}

We thank R. Dubiel, J.G. Fleagle, and K.D. Rose for review of the first draft of this manuscript, and D.E. Fastovsky and one anonymous reviewer for the journal. A. Aslan, K.C. Beard, J.G. Fleagle, C.N. Larriestra, K.D. Rose, and S.L. Wing provided informative discussion. Collection of all paleosol maturation stage data was funded by $\mathrm{Na}$ tional Geographic Society grant \#3985-89 to T.M. Bown. M.J. Kraus acknowledges National Science Foundation grants EAR-8608152 and EAR-8810972, and nearly all paleontologic data were collected under the auspices of $\mathrm{Na}$ tional Science Foundation grants BSR-8215099, BSR8500732, and BSR-8918755 to K.D. Rose. Development of the concepts presented herein was greatly augmented by field observations in formations other than the Willwood, and we acknowledge support from National Science Foundation grants BNS-90-12154 to J.G. Fleagle and BNS-8209937 to E.L. Simons.

\section{REFERENCES}

AsLaN, A., 1990, Paleotopographic controls on hydromorphic paleosol development in the Willwood Formation, Bighorn Basin, Wyoming: unpublished MS thesis, University of Colorado, Boulder, $139 \mathrm{p}$.

BADGLEy, C., and Gingerich, P.D., 1988, Sampling and faunal turnover in early Eocene mammals: Palaeogeography, Palaeoclimatology, Palaeoecology, v. 63, p. 141-157.

Bilzi, A.F., and Ciolkosz, E.J., 1977, A field morphology rating scale for evaluating pedological development: Soil Science, v. 124, p. $46-48$.

BLACKWELDER, E., 1909, The valuation of unconformities: Journal of Geology, v. 17, p. 289-299.

Bown, T.M., 1979, Geology and mammalian paleontology of the Sand Creek facies, lower Willwood Formation (lower Eocene), Washakie County, Wyoming: Geological Survey of Wyoming Memoir 2, $151 \mathrm{p}$.

Bown, T.M. 1980, The Willwood Formation (lower Eocene) of the southern Bighorn Basin, Wyoming, and its mammalian fauna: University of Michigan Papers on Paleontology, v. 24, p. 127-138.
Bown, T.M., 1982, Geology, paleontology, and correlation of Eocene volcaniclastic rocks, southeast Absaroka Range, Hot Springs County, Wyoming: U.S. Geological Survey Professional Paper, 1201-A, 75 p.

Bown, T. M., 1984, Biostratigraphic significance of baselevel changes during deposition of the Willwood Formation (lower Eocene), Bighorn Basin, northwest Wyoming: Geological Society of America Abstracts with Programs, v. 16, p. 216.

Bown, T. M., 1985, Maturation sequences in lower Eocene alluvial paleosols, Willwood Formation, Wyoming: in Flores, R.M., and HARVEY, M., eds., Field Guidebook to Modern and Ancient Fluvial Systems in the United States: Fort Collins, Third International Fluvial Sedimentology Conference, p. 20-26.

Bown, T.M., 1987, The mammalian pedofacies; a novel approach to detailed verticolateral and temporal controls in vertebrate facies distribution and mammalian evolution: Geological Society of American Abstracts with Programs, v. 19, p. 262.

Bown, T.M., and BEARD, K.C., 1990, Systematic lateral variation in the distribution of fossil mammals in alluvial paleosols, lower Eocene Willwood Formation, Wyoming: in Bown, T.M., and Rose, K.D., eds., Dawn of the Age of Mammals in the Northern Part of the Rocky Mountain Interior, North America: Geological Society of America Special Paper 243, p. 135-151.

Bown, T.M., and KRAUS, M.J., 1981a, Lower Eocene alluvial paleosols (Willwood Formation, northwest Wyoming, U.S.A.), and their significance for paleoecology, paleoclimatology, and basin analysis: Palaeogeography, Palaeoclimatology, Palaeoecology, v. 34, p. 130.

Bown, T.M., and Kraus, M.J., 1981b, Vertebrate fossil-bearing paleosol units (Willwood Formation, lower Eocene, northwest Wyoming, U.S.A.): Implications for taphonomy, biostratigraphy, and assemblage analysis: Palaeogeography, Palaeoclimatology, Palaeoecology, v. 34, p. 31-56.

Bown, T.M., and KRAUS, M.J., 1987, Integration of channel and floodplain suites, I. Developmental sequence and lateral relations of alluvial paleosols: Journal of Sedimentary Petrology, v. 57, p. 587601.

Bown, T.M., and Larriestra, C.N., 1990, Sedimentary paleoenvironments of fossil platyrrhine localities, Miocene Pinturas Formation, Santa Cruz Province, Argentina: Journal of Human Evolution, v. 19, p. 87-119.

Bown, T.M., and Rose, K.D., 1987, Patterns of dental evolution in early Eocene anaptomorphine primates (Omomyidae) from the Bighorn Basin, Wyoming: Paleontological Society Memoir 23, 162 p.

Bown, T.M., Rose, K.D., Simons, E.L., and Wing, S.L., in press, Distribution and stratigraphic correlation of fossil mammal and plant localities in the Fort Union, Willwood, and Tatman formations (upper Paleocene-lower Eocene), central and southern Bighorn Basin, Wyoming: U.S. Geological Survey Professional Paper.

BRIDGE, J.S., and LEEDER, M.R., 1979, A simulation model of alluvial stratigraphy: Sedimentology, v. 26, p. 617-644.

BRIDGES, E.M., 1973, Some characteristics of alluvial soils in the Trent Valley, England: International Soil Science Society Transactions, 5th and 6th Comm., p. 247-253.

FARLEY, M.B., 1989, Palynological facies fossils in nonmarine environments in the Paleogene of the Bighorn Basin: PALAIOS, v. 4 , p. $565-573$.

FARLEY, M.B., 1990, Vegetation distribution across the early Eocene depositional landscape from palynological analysis: Palaeogeography, Palaeoclimatology, Palaeoecology, v. 79, p. 11-27.

Friend, P.F., Johnson, N.M., and McRAE, L.E., 1989, Time-level plots and accumulation patterns of sediment sequences: Geological Magazine, v. 126, p. 491-498.

GiNGERICH, P.D., 1983, Paleocene-Eocene faunal zones and preliminary analysis of Laramide structure deformation in the Clark's Fork Basin, Wyoming: Wyoming Geological Association Guidebook, 34th Annual Field Conference, p. 185-195. 
GINGERICH, P.D., 1989, New earliest Wasatchian mammalian fauna from the Eocene of northwestern Wyoming: Composition and diversity in a rarely sampled high-floodplain assemblage: University of Michigan Papers on Paleontology, v. 28, p. 1-97.

Granger, W., 1914, On the names of lower Eocene faunal horizons of Wyoming and New Mexico: American Museum of Natural History Bulletin, v. 33, p. 201-207.

Guthrie, D.A., 1967, The mammalian fauna of the Lysite Member, Wind River Formation (early Eocene) of Wyoming: Memoir, Southern California Academy of Science, v. 5, p. 1-53.

GuTHRIE, D.A., 1971, The mammalian fauna of the Lost Cabin Member (lower Eocene) of Wyoming: Annals of the Carnegie Museum, v. 45 , p. $47-113$.

HARDEN, J.W., 1982, A quantitative index of soil development from field descriptions: Examples from a chronosequence in central California: Geoderma, v. 28, p. 1-28.

Hewet, D.F., 1926, Geology and oil and coal resources of the Oregon Basin, Meeteetse, and Grass Creek Basin quadrangles, Wyoming: U.S. Geological Survey Professional Paper 145, 111 p.

HiCKey, L., 1980, Paleocene stratigraphy and flora of the Clark's Fork Basin: University of Michigan Papers on Paleontology, v. 24, p. 33-49.

KEEFER, W.R., 1965, Geologic history of Wind River Basin, Wyoming: American Association of Petroleum Geologists Bulletin, v. 49, p. 1878-1892.

KeEfer, W.R., AND Troyer, M.L., 1956, Stratigraphy of the Upper Cretaceous and Lower Tertiary rocks of the Shotgun Butte area, Fremont County, Wyoming: U.S. Geological Survey Oil \& Gas Investigations, Preliminary Chart, OC-56.

Kraus, M.J., 1980, Genesis of a fluvial sheet sandstone, Willwood Formation, northwest Wyoming: University of Michigan Papers on Paleontology, v. 24, p. 87-94.

KraUS, M.J., 1987, Integration of channel and floodplain suites, II. Vertical relations of alluvial paleosols: Journal of Sedimentary Petrology, v. 57, p. 602-612.

KraUs, M.J., and Bown, T.M., 1986, Paleosols and time resolution in alluvial stratigraphy: in WRIGHT, V.P., ed., Palaeosols: Their recognition and interpretation: Blackwell, London, p. 180-207.

LEEDER, M.R., 1975, Pedogenic carbonates and flood sediment accretion rates: A quantitative model for alluvial arid-zone lithofacies: Geological Magazine, v. 112, p. 257-270.

Love, J.D., 1939, Geology along the southern margin of the Absaroka Range, Wyoming: Geological Society of American Special Paper $20,133 \mathrm{p}$.

McGowran, B., 1990, Fifty million years ago: American Scientist, v. 78, p. 30-39.

Molnar, P., and England, P., 1990, Late Cenozoic uplift of mountain ranges and global climate change: Chicken or egg?: Nature, v. 346, p. $29-34$.

NeASHAM, J.W., and VoNDRA, C.F., 1972, Stratigraphy and petrology of the lower Eocene Willwood Formation, Bighorn Basin, Wyoming: Geological Society of America Bulletin, v. 83, p. 2167-2180.

Retallack, G.J., 1984, Completeness of the rock and fossil record: Some estimates using fossil soils: Paleobiology, v. 10, p. 59-78.

RETALlaCK, G.J., 1986, Fossil soils as grounds for interpreting longterm controls on ancient rivers: Journal of Sedimentary Petrology, v. 56, p. $1-18$.
RETALLACK, G.J., 1991, Untangling the effects of burial alteration and ancient soil formation: Annual Review of Earth and Planetary Science, v. 19, p. 183-206.

Rose, K.D., 1981, The Clarkforkian land-mammal age and mammalian faunal composition across the Paleocene-Eocene boundary: University of Michigan Papers on Paleontology, v. 26, p. 1197.

SCHANKLER, D. M., 1980, Faunal zonation of the Willwood Formation in the central Bighorn Basin, Wyoming: University of Michigan Papers on Paleontology, v. 24, p. 99-114.

SCHANKLER, D.M., 1981, Local extinction and ecological re-entry of early Eocene mammals: Nature, v. 293, p. 135-138.

Sloss, L.L., Krumbein, F.C., and Dapples, E.C., 1949, Integrated facies analysis: Geological Society of America Memoir 39, p. 91 124.

Smith, N.D., Cross, T.A., Dufficy, J.P., and Clough, S.R., 1989, Anatomy of an avulsion: Sedimentology, v. 36, p. 1-23.

STUCKY, R., 1984a, Revision of the Wind River faunas, early Eocene of central Wyoming, part 5. Geology and biostratigraphy of the upper part of the Wind River Formation, northeastern Wind River Basin: Annals of the Carnegie Museum, v. 53, p. 231-294.

STUCKY, R., 1984b. The Wasatchian-Bridgerian land mammal age boundary (early to middle Eocene) in western North America: Annals of the Carnegie Museum, v. 53, p. 347-382.

VAIL, P.R., HARDENBOL, J., and TodD, R.G., 1984, Jurassic unconformities, chronostratigraphy, and sea-level changes from seismic stratigraphy and biostratigraphy: in SCHLEE, J.S., ed., Interregional Unconformities and Hydrocarbon Accumulation: American Association of Petroleum Geologists Memoir 36, p. 129-144.

VAN Houten, F.B., 1944, Stratigraphy of the Willwood and Tatman formations in northwestern Wyoming: Geological Society of American Bulletin, v. 55, p. 165-210.

WheELER, H.E., 1958, Time-stratigraphy: American Association of Petroleum Geologists Bulletin, v. 42, p. 1047-1063.

WING, S.L., 1980, Fossil floras and plant-bearing beds of the central Bighorn Basin: University of Michigan Papers on Paleontology, v. 24 , p. $119-125$

WING, S.L., 1984, Relation of paleovegetation to geometry and cyclicity of some fluvial carbonaceous deposits: Journal of Sedimentary Petrology, v. 54, p. 52-66.

WiNTERFELD, G.F., 1986, Laramide tectonism, deposition, and Early Cenozoic stratigraphy of the northwestern Wind River Basin and Washakie Range, Wyoming: Unpublished Ph.D. Dissertation, University of Wyoming, Laramie, $248 \mathrm{p}$.

WoLFE, J.A., 1989, North American Eocene vegetation and its climatic implications: Transactions of the American Geophysical Union (EOS), v. 70, p. 375.

Wood, H.E. II, Chaney, R.W., Clark, J., Colbert, E.H., Jepsen, G.L., ReEside, J.B., JR., and STOCK, C., 1941, Nomenclature and correlation of the North American continental Tertiary: Geolog ical Society of American Bulletin, v. 52, p. 1-48.

ACCEPTED JANUARY 6, 1992 